\title{
Labyrinthe
}

$5 \mid 2000$

Numéro 5

\section{Mount Eagle}

traduit de l'anglais par Elishéva Marciano

John Montague

\section{(2) OpenEdition}

Journals

Édition électronique

URL : http://journals.openedition.org/labyrinthe/274

DOI : $10.4000 /$ labyrinthe. 274

ISSN : 1950-6031

Éditeur

Hermann

Édition imprimée

Date de publication : 15 janvier 2000

Pagination : 99-111

Référence électronique

John Montague, « Mount Eagle », Labyrinthe [En ligne], 5 | 2000, mis en ligne le 18 février 2005,

consulté le 25 avril 2019. URL : http://journals.openedition.org/labyrinthe/274 ; DOI : 10.4000/

labyrinthe. 274

Ce document a été généré automatiquement le 25 avril 2019.

Propriété intellectuelle 


\section{Mount Eagle}

traduit de l'anglais par Elishéva Marciano

John Montague

1 Le prix Nobel de littérature a, en 1995, récompensé un poète irlandais, Seamus Heaney, faisant entendre hors de son île les voix de l'Irlande.

2 Seamus Heaney fait partie de cette génération de poètes contemporains qui, dans la continuité de la Renaissance littéraire irlandaise du XIXe siècle, font vivre la mythologie celte, l'histoire, les conflits, les paysages et les habitants de cette île divisée.

Ces poètes ont pour nom John Hewitt, Michael Longley, Derek Mahon et John Montague.

4 John Montague est né à Brooklyn en 1929, de parents irlandais ayant choisi l'exil pour raisons politiques, mais il est élevé en Irlande dès l'âge de quatre ans. Il vit actuellement à Cork. Marié deux fois à des Françaises, il connaît parfaitement notre pays et notre langue mais, curieusement, très peu de ses œuvres ont été traduites en français.

Les poèmes cités dans ce numéro de Labyrinthe sont extraits d'un recueil relativement récent, Mount Eagle, publié en Irlande en 1988. Ils font partie d'un ensemble de poèmes qui portent tous l'empreinte de l'Irlande mais qui, parce qu'ils sont écrits en anglais et non en gaélique, appartiennent à ce que l'on appelle la littérature anglo-irlandaise et non à la littérature irlandaise.

En effet, bien qu'après la fondation de la république (1948) les poètes irlandais soient devenus, en grande majorité, bilingues, ils choisissent, pour la plupart, d'écrire en anglais, pressentant que le gaélique n'avait pas de véritable avenir et que seul l'anglais leur permettrait d'atteindre et d'influencer un vaste public. Il faut en effet reconnaître que, malgré les efforts du gouvernement pour généraliser l'apprentissage du gaélique à l'école, la république d'Irlande reste une nation de langue anglaise et seulement $2,5 \%$ de la population utilise le gaélique, principalement dans les comtés du Donegal et du Kerry, cette partie de l'île que l'on nomme Gaeltacht.

7 Certains poètes écrivent néanmoins en gaélique, comme Nuala Ni Dhomhnaill, dont les œuvres ont été traduites en anglais, par, entre autres, John Montague, ainsi que l'on peut le constater dans « La poupée cassée ».

8 De toutes les façons, remarque John Montague dans The Figure in the Cave, un essai (non traduit) sur sa vie et son œuvre, "qu'ils utilisent le gaélique ou l'anglais, tous les poètes irlandais 
partagent la même tradition. » Cette tradition plonge ses racines dans la mythologie celte, dans la littérature du temps des bardes, dans l'histoire ancienne et contemporaine et ses douleurs; comme dans la terre d'Irlande, tantôt sauvage (Luggala), tantôt paysanne (Le Chant du foyer) ; également dans une langue gaélique qui resurgit ici et là, dans certains mots, comme dans le poème "Tête blonde ». Autant d'éléments qui contribuent à marquer Mount Eagle du sceau de l' " irishness ».

Mais, si la dimension référentielle de Mount Eagle est essentielle, elle ne doit pas réduire les poèmes à leur thématique et occulter leur essence qui est, non ce qu'ils veulent dire, mais comment ils le disent. Ce qui frappe dans ces poèmes, c'est leur qualité picturale, en particulier lorsque le poète décrit physiquement une femme. "Ton visage enfoui sous tes longs cheveux » (" Matines »), " ta/chevelure éblouissante, ton corps opulent ", "tes formes généreuses, pluie/d'or au clair de lune " ("Moisson») ont un puissant pouvoir de suggestion. La chevelure et le corps semblent être les éléments féminins qui attirent le plus le poète. Le corps de la femme est dépeint dans sa plénitude, comme dans les tableaux de Rubens. Dans "Parc aux cerfs", qui décrit une jeune courtisane, la présence féminine est particulièrement charnelle, presque " palpable », avec un chapelet d'adjectifs : palpables, charnus, effronté, camus, dodues, parfumées, roux, rosée, qui évoquent une sensualité évidente et font appel à tous nos sens.

Pour définir le talent de Montague dans Mount Eagle, il faudrait aussi parler de son art de la métaphore, qui éclate dans Ballade pour Berryman, où le mot " heady ", que j'ai traduit par " grisant(s) » veut dire " qui monte à la tête », " enivrant ». Il rappelle les fameuses " cuites » de Montague et de Berryman et l'image qu'il contient est développée dans la deuxième strophe avec le mot " grogs » et la métaphore de la décantation et de la fermentation de l'alcool pour décrire la longue élaboration des Dream Songs.

11 Les poèmes de Mount Eagle sont denses et riches, significatifs de l'art d'un poète qui se définit luimême comme "le chaînon manquant de la poésie de l'Ulster car il n'y a pas eu de poète issu de l'Ulster catholique depuis les poètes gaéliques du VIII siècle.»

Hearth Song

for Seamus Heaney

121

The Nialls'cottage had one :

it lived under a large flagstone, loving the warmth of the kitchen.

13 Chill or silent, for whole days, it would, all of a sudden, start its constant, compelling praise. And all of us, dreaming or chatting over the fire, would go quiet, harkening to that insistent creak,

14 Accustoming ourselves all over again to that old, but always strange sound, coming at us from under the ground,

15 Rising from beneath our feet, welling up out of the earth, a solitary, compulsive song

16 Composed for no one, a tune dreamt up under a flat stone, earth's fragile, atonal rhythm. 
And did I once glimpse one?

I call up that empty farmhouse, its blind, ghostly audience

18 And a boy's bare legs dangling down from a stool, as he peers through a crack in the flagstones

19 And here it strikes up again, that minute, manic cellist, scraping the shape of itself, its shining, blue-black back and pulsing, tendril limbs throbbing and trembling in darkness

21 a hearth song of happiness.

\section{Le Chant du Foyer} pour Seamus Heaney

231

La chaumière des Niall en avait un :

il vivait sous une grosse dalle aimant la tiédeur de la cuisine.

24 Des jours entiers, glacial, il se taisait, pour entonner brusquement son incessant, irrésistible chant de gloire. Et nous, qui rêvions ou causions au coin du feu, nous faisions silence, prêtant l'oreille à ce crissement insistant,

25 Nous réhabituant comme pour un commencement à ce bruit connu mais toujours surprenant, qui sortait du sol pour nous parvenir,

26 S'élevait de sous nos pieds, jaillissait de la terre, chant solitaire et machinal,

27 Air sans destinataire, conçu sous une pierre plate, rythme venu de la terre, fragile, atonal.

28

En ai-je jamais entrevu?

Je revois cette ferme nue, peuplée de fantômes comme dans un brouillard

29 Et un petit garçon juché sur un tabouret, qui scrute une fente dans la pierre tout en balançant ses jambes nues 
qu'aussitôt, violoncelliste cyclothymique

il entonne à nouveau sa mélodie,

frottant ses élytres fantomatiques,

31 Son dos brillant, d'un noir bleuté

et ses membres repliés, palpitants,

vibrant et tremblant dans les ténèbres

32

chant d'allégresse du foyer.

Deer Park

\begin{tabular}{|c|c|}
\hline & Parc aux Cerfs \\
\hline A flourish of silver & Une fanfare d'argent \\
\hline trumpets as the royal & éclate tandis qu'on prépare \\
\hline favourite is prepared & la favorite du roi \\
\hline for the swansdown bed. & pour la couche en duvet d'oie \\
\hline Fingers and toes & Doigts et orteils \\
\hline palpable, succulent & palpables, charnus \\
\hline as those pert curves & comme cette bouche au contour \\
\hline of mouth, snub nose. & effronté, ce nez camus. \\
\hline The string of pearls & Les perles sur plusieurs rangs \\
\hline on her stomach folds & s'enroulent autour de son buste \\
\hline luminously pendent & suspendues dans la lumière \\
\hline like rare raindrops & comme de précieuses gouttes de pluie \\
\hline While a pair of pure- & Tandis que deux chiens \\
\hline bred hunting hounds & de chasse pure race \\
\hline snuffle her plump & reniflent ses mains \\
\hline and perfumed hands. & dodues et parfumées. \\
\hline A candid light streams & Une lumineuse innocence jaillit \\
\hline from such guileless, & de cette nudité potelée \\
\hline dimpled nakedness, such & si candide, de cette \\
\hline
\end{tabular}




\begin{tabular}{|c|c|}
\hline cherubic openness! & limpidité si angélique! \\
\hline And the fillet of & Et la résille d'or \\
\hline gold she bears so & qu'elle porte d'un air \\
\hline demurely in honour & si modeste en l'honneur \\
\hline of her sovereign master, & de son seigneur et maître, \\
\hline Upon her piled strands & Sur les mèches luxuriantes \\
\hline of auburn Irish hair, & de ses cheveux roux d'Irlandaise, \\
\hline looped to reveal her & est nouée de façon à découvrir son \\
\hline golden neck collar. & tour de cou en or. \\
\hline A kings's treasure & Trésor de roi \\
\hline of roseate flesh & à chair rosée \\
\hline caught on canvas & saisi sur toile \\
\hline for a king's pleasure & pour le plaisir d'un roi \\
\hline With a full quiver & Avec un plein carquois \\
\hline of arrows, a dangling & de flèches et, pendant, \\
\hline brace of pheasant & un couple de faisans, \\
\hline all stamped : royal property. & tous estampés : propriété du roi \\
\hline
\end{tabular}

\section{Matins}

That final bright morning you climb

The stairs to my balcony bed,

Unasked; unashamed: naked.

Barely a please was said

But in the widening light

Our bodies linked, blazed,

Our spirits melded. The dawn

of a capital city swarmed

Beneath us, but we were absorbed,

Your long hair tenting your head,

Your body taut as a divining rod.

There is in such exchanges a harvest, 
A source or wellspring of sweetness,

Grace beyond sense, body's intelligence.

Les marches menant à mon lit balcon, sans invitation ; sans honte : nue

Avec tout juste un je t'en prie mais dans la lumière grandissante Nos corps s'unirent, s'embrasèrent, Nos esprits se fondirent. L'aube D'une capitale fourmillait Au-dessous de nous, mais nous étions absorbés, Ton visage enfoui sous tes longs cheveux,

Ton corps tendu comme une baguette de sourcier.

Il y a dans de tels échanges une moisson,

Un jaillissement de douceur,

Grâce au-delà du sens, intelligence du corps.

Harvest

That first wild summer

we watched each other, my graying hair and wary eyes slowly drawn to be warmed by your flaring hair, abundant body.

37 No ice princess, you call me down from my high tower on our first night together I awoke, to watch over your rich shape, a shower of gold in the moonlight.

38 And an old fable stirred:

a stag rising from a wet brake, - Danae deluged by Zeus? Rather, youth's promise fulfilled, homely as a harvest field from my Tyrone childhood here I hoist warm sheaves to tent them into golden stooks, each detail, as I wade through the moonlit stubble, crayon bright, as in a child's colouring-book.

Moisson

41 En ce premier été torride nous nous observâmes, mes cheveux grisonnants et 
mes yeux prudents lentement attirés

pour être embrasés par ta

chevelure éblouissante, ton corps opulent.

Princesse non point de glace, tes appels me font descendre du haut de ma tour lors de notre première nuit ensemble je m'éveillai, pour contempler tes formes généreuses, pluie d'or au clair de lune.

Et un vieux mythe me revint :

un taureau qui surgit d'un hallier humide, - Danae inondée par Zeus?

Plutôt, la promesse qu'annonçait l'âge tendre, simple comme un champ moissonné dans le Tyrone de mon enfance

44 Où je hisse des gerbes tièdes pour les assembler en moyettes dorées, chaque détail, tandis que j'avance parmi le chaume sous la lune, d'un éclat de sanguine, comme dans l'album de coloriage d'un enfant.

Nest

When all the birds

in the nest are there, is that the start of a new despair?

Nid

47 Quand tous les oiseaux

dans le nid sont blottis, est-ce le départ d'un nouveau désespoir?

The Broken Doll

O little broken doll, dropped in the well, thrown aside by a child, scampering downhill to hide under the skirts of his mother ! In twilight's quiet he took sudden fright as toadstool caps snatched at his tongue, foxgloves crooked their fingers at him and from the oak, he heard the owl's low call. His little heart almost stopped when a weasel went by, a fat young rabbit in its jaws, loose guts spilling over the grass while a bat wing flicked across the evening sky. He rushed away so noisily and ever since you are a lasting witness to the fairy arrow that stabbet his ear ; stuck in the mud your plastic eyes squinny open from morning to night : you see the vixen and her brood 
stealing up to lap the ferny swamphole near their den, the badger loping to wash his paws, snuff water with his snout. On Pattern days people parade seven clockwise rounds ; at every turn, throwing in a stone.

Those small stones rain down on you.

The nuts from the hazel tree that grows to the right of the well also drop down : you will grow wiser than any blessed trout in this ooze! The redbreasted robin of the Sullivans will come to transform the surface to honey with her quick tail, churn the depths to blood, but you don't move. Bemired, your neck strangled with lobelias, I see your pallor staring starkly back at me from every swimming hole, from every pool, Ophelia.

After the Irish of Nuala Ni Dhomhnaill

\section{qui dévale la colline pour se cacher sous les jupes} de sa mère après t'avoir jetée dans le puits !

Dans le silence crépusculaire il avait soudain pris peur :

les chapeaux des champignons vénéneux lui sautaient au visage, les digitales le menaçaient de leurs doigts crochus et du haut de son chêne, le hibou hululait.

Son petit cœur s'était presque arrêté au passage d'une fouine, un lapereau bien gras entre les dents, éventré, perdant ses tripes sur l'herbe tandis que d'un coup d'aile une chauve-souris fendait le ciel nocturne.

Il avait fui si bruyamment et depuis

tu es et resteras témoin de la flèche magique qui perça son oreille; embourbée, yeux de plastique à demi ouverts de l'aube à la nuit, tu vois la renarde et ses petits aller sans bruit boire à la mare envahie de fougères près de leur antre, le blaireau bondir pour se laver les pattes et se désaltérer. Les jours de procession ${ }^{1}$ on tourne sept fois dans le sens des aiguilles d'une montre, en jetant un caillou à chaque tour.

54 Ces petits cailloux pleuvent sur toi.

Tombent aussi les fruits du noisetier ${ }^{2}$ qui pousse à la droite du puits : dans cette boue tu surpasseras en sagesse la plus avisée des truites! Le rouge-gorge des Sullivan viendra et de sa queue agile il changera la surface en miel, 
les profondeurs en sang, mais tu restes immobile.

La vase te recouvre, les lobélies enserrent ton cou, chaque étang, chaque mare me renvoie

ton regard délavé qui me fixe, Ophélie.

D'après le poème en irlandais de Nuala Ni Dhomhnaill ${ }^{3}$

Luggala

for Garech Browne

$55 \quad$ I

Again and again in dream, I return to that shore. There is a wind rising, a gull is trying to skim over the pines, and the waves whisper and strike along the bright sickle of the little strand. Shoving through reeds and rushes, leaping over a bogbrown stream, I approach the temple by the water's edge, death's shrine, cornerstone of your sadness. I stand inside, by one of the pillars of the mausoleum, and watch the water in the stone basin. As the wind ruffles cease, a calm surface appears, like a mirror or crystal. And into it your face rises, sad beyond speech, sad with an acceptance of blind, implacable process. For by this gray temple are three tombs, a baby brother, a half-sister and a grown brother, killed at twenty-one. Their monuments of Wicklow granite are as natural here as the scattered rocks, but there is no promise of resurrection, only the ultimate silence of the place, the shale littered face of the scree, the dark, dark waters of the glacial lake.

The road leading from the white wedding cake of the hunting lodge is lined with late blooming daffodils. As you leave, it fades back into its mountain setting, a folly nestling under boulder-strewn granite cliffs, with a stream rushing down by its side. Under the trunk of each tree, flowers shelter, and there is a path leading down to the lake. You push open a wooden gate and a herd of deer starts away, ears pricked, eyes alert, nimblelegged. Then they halt at a distance, tensely shy, but curious. The path twists and turns, following bends of the bogbrown stream. In the wooden hollow of the boathouse you pull and tug ropes until the boat descends with a splash into dark, lapping waters. Oar blades rise and fall and soon you are at the heart of the lake with the hills forming a circle, you the centre.

III

But you ar not alone : a noise disturbs you, rhytmic as the beat of oars. A mother swan is teaching her young to fly : round and round in that protecting silence they turn, necks timidly outstretched, wings slowly beating. Now and again one falls, breaking its reflection in the lake, then struggling upwards to join its fellows. And then you realise there is another, still greater presence. Motionless and gray, the huge cliff hangs upsidedown in the mirror of the lake ; water, mountain and forest held in lasting embrace.

Luggala

pour Garech Browne

59

Maintes fois en rêve, je retourne vers ce rivage. Il y a un vent qui se lève, une mouette s'essaie à raser la cime des pins, et les vagues murmurent et frappent la faucille claire de l'étroite berge. Me frayant un chemin à travers roseaux et joncs, sautant un ruisseau tourbeux, j'at-teins le temple au bord de l'eau, sanctuaire de la mort, pierre angulaire de ta tristesse. J'entre à l'intérieur et je reste debout, près d'un des piliers du mausolée, à 
regarder l'eau dans le bassin de pierre. Comme le vent s'apaise, une surface calme apparait, comme un miroir ou du cristal. Et dans ce miroir ton visage se dessine, triste audelà des mots, triste avec l'acceptation d'un processus aveugle, implacable. Car près de ce morne temple sont trois tombes, celles d'un frère tout bébé, d'une demi-sœur, et d'un grand frère tué à vingt-et-un ans. Leurs monuments de granit du Wicklow sont aussi naturels ici que les rochers éparpillés, mais il n'existe pas de promesse de résurrection, seulement l'ultime silence du lieu, la surface de l'éboulis couverte de schiste, les eaux sombres, sombres du lac glaciaire.

La route qui part du pavillon de chasse en forme de pièce montée est bordée de jonquilles à la floraison tardive. À mesure que tu t'éloignes, il s'efface pour retourner dans son cadre de montagnes, folie nichée sous des falaises de granit jonchées de grosses pierres, avec un ruisseau dévalant à ses côtés. Sous le tronc de chaque arbre, s'abritent des fleurs, et il y a un sentier qui mène au lac. Tu pousses une barrière de bois, et un troupeau de biches s'enfuit, oreilles dressées, yeux vifs, pattes agiles. Puis elles s'arrêtent en se tenant à distance, craintives, mais curieuses. Le sentier zigzague, suivant les coudes du ruisseau bourbeux. Dans le creux boisé de l'abri à bateaux tu tires sur les cordages jusqu'à ce que le bateau descende avec un plouf dans les eaux noires et clapotantes. Les rames se mettent en mouvement et bientôt tu es au cœur du lac avec les collines formant un cercle dont tu es le centre.

Mais tu n'es pas seul : un bruit te trouble, rythmé comme le battement des rames. Une mère cygne apprend à voler à ses petits : dans ce silence protecteur, ils tournoient, en allongeant timidement le cou et en battant des ailes. Par moments l'un tombe, brisant son reflet dans le lac, alors il lutte de toutes ses forces pour s'élever et rejoindre ses compagnons. C'est alors que tu remarques une autre présence, encore plus grande. Immobile et grise, l'immense falaise est suspendue à l'envers dans le miroir du lac ; eau, montagne et forêt enlacées pour l'éternité.

\section{ANNEXES}

Elishéva Marciano est titulaire d'une maitrise de littérature anglaise dont le mémoire consistait en une traduction, avec introduction et notes, d'un recueil de poésie, Mount Eagle, de John Montague. Après un DESS de traduction littéraire professionnelle, elle est actuellement traductrice et travaille pour l'édition et l'audiovisuel (traduction de documentaires pour la télévision). Elle fait partie du comité de lecture (langue anglaise) de la Maison Antoine Vitez, centre international de la traduction théâtrale. Cuvres traduites : Mount Eagle (poésie) de John Montague, non publié ; Frank et Billy (roman) de Laurie Colwin, aux Éditions Autrement ; Insurrection : l'histoire à bras-le-corps (théâtre) de Robert O'Hara, à paraître aux Éditions Les Solitaires intempestifs. Elle traduit en ce moment un roman anglais contemporain, Splitting, de Fay Weldon à paraître en l'an 2000 aux Éditions Joëlle Losfeld. 


\section{NOTES}

1. Pattern day : en Irlande, jour d'un Saint Patron et les festivités qui le célèbrent.

2. Dans la mythologie celte, les fruits du noisetier donnent la sagesse.

3. Poétesse irlandaise, née dans le Lancashire en 1952, élevée dans le comté de Kerry (dans le Gaeltacht). Vit actuellement à Dublin. 